\title{
Reproduction and gene flow in the genus Quercus $L$
}

\author{
A Ducousso 1, H Michaud 2, R Lumaret 2 \\ 1 INRA, BP 45, 33611 Gazinet-Cestas; \\ ${ }^{2}$ CEFE/CNRS, BP 5051, 34033 Montpellier Cedex, France
}

\begin{abstract}
Summary - In this paper we review the characteristics of the floral biology, life cycle and breeding system in the genus Quercus. The species of this genus are self-incompatible and have very long life spans. The focus of our review is on the effects of gene flow on the structuration of genetic variation in these species. We have examined the influence of gene flow in 2 ways: 1) by measuring the physical dispersal of pollen, seed and vegetative organs; and 2) by using nuclear and cytoplasmic markers to estimate genetic parameters $\left(F_{i s}, N_{m}\right)$. These approaches have shown that nuclear (isozyme markers) as well as cytoplasmic (chloroplastic DNA) gene flow is usually high, so that very low interspecific differentiation occurs. However, intraspecific differentiation is higher for the cytoplasmic DNA than for the nuclear isozyme markers.
\end{abstract}

\section{floral biology / life cycle / breeding system / gene flow / oak}

Résumé - Système de reproduction et flux de gènes chez les espèces du genre Quercus. Les caractéristiques de la biologie florale, du cycle de vie et du système de reproduction ont été analysées pour les espèces du genre Quercus. Ces espèces sont auto-incompatibles et à très longue durée de vie. Les effets des flux de gènes sur la structuration de la variabilité génétique ont aussi été étudiés de 2 manières. D'une part, grâce aux mesures de la dispersion du pollen, des graines et des organes végétatifs, et, d'autre part, en utilisant des paramètres génétiques $\left(F_{i s}, N_{m}\right)$ obtenus à partir des marqueurs nucléaires et cytoplasmiques. II apparaît que les flux géniques nucléaires (isozymes) et cytoplasmiques (ADN chloroplastique) sont en général importants, d'où une faible différenciation interspécifique. Néanmoins la différenciation intraspécifique est plus forte lorsqu'elle est estimée à partir des marqueurs cytoplasmiques que lorsqu'elle l'est à partir des marqueurs nucléaires. 


\section{INTRODUCTION}

Plant populations show a significant amount of organization in the genetic variation they contain (Wright, 1951). Such organization is significantly influenced by joint action of mutation, migration, selection and genetic drift. In this context, gene flow among plant populations may represent a significant factor influencing the maintenance of genetic organization in plant species populations (Slatkin, 1987). Gene flow is generally considered to be both small enough to permit substantial local genetic differentiation (Levin and Kerster, 1974), and large enough to introduce variability into widely separated populations (Loveless and Hamrick, 1984). This is particularly important in outbreeding, perennial and iteroparous species, such as forest trees.

In the present paper, the influences of the mating system and factors operating on gene flow at different stages of the life cycle are reviewed in various species of the genus Quercus.

\section{REPRODUCTIVE SYSTEM}

\section{Floral biology}

Species of the genus Quercus (the oaks) are predominantly monoecious with distinct male and female flowers borne on 2 types of inflorescences; very occasionally they bear hermaphroditic flowers or inflorescences (Scaramuzzi, 1958; Stairs, 1964; Tucker, 1972; Bonnet-Masimbert, 1978; Tucker et al, 1980). The characteristics of male and female flowers are summarized below.

\section{Staminate flowers}

Male flowers are grouped in catkins which develop in the axils of either the inner bud scales or the first leaves, in the lower part of the branches produced in the same year. Staminate inflorescences are initiated in late spring, flowers develop in early summer and meiosis occurs in the following spring, giving rise to binucleate pollen grains immediately prior to the emergence of catkins (Sharp and Chisman, 1961; Stairs, 1964; Tucovic and Jovanovic, 1970; Hagman, 1975; Bonnet-Masimbert, 1978; Merkle et al, 1980). For a given tree, if weather conditions are suitable, catkin growth is achieved 1-2 weeks after bud opening, and pollination is completed in 24 days (Sharp and Chisman, 1961; Stairs, 1964; Vogt, 1969; Lumaret et al, 1991). In deciduous oaks, leaf expansion ceases during the release of pollen, which allows freer movement of pollen (Sharp and Chisman, 1961).

\section{Pistillate flowers}

Female flowers appear in the axils of leaves produced in the same year. They are produced on a short stalk and become visible a few days after the emergence of the male catkins (Sharp and Sprague, 1967). Inflorescence primordia are difficult to distinguish from lateral bud primordia before late summer, hence the exact time of the initiation of pistillate inflorescences is difficult to determine. As hermaphrodite flowers are known to occur occasionally, Bonnet-Masimbert (1978) has hypothesized that their initiation may occur in late spring, when the staminate inflorescences develop. Female flowers develop in late winter or early spring (Bonnet-Masimbert, 1978; Merkle et al, 1980). Each flower is 
included in a cupule, which is regarded as homologous to a third-order inflorescence branch (Brett, 1964; McDonald, 1979). During elongation of the stalk, 3-5 styles emerge from the cupule and become reddish and sticky when receptive (Corti, 1959; Sharp and Sprague, 1967; Rushton, 1977). Stigma receptivity for a single flower may last up to $6 \mathrm{~d}$ and $10-14 \mathrm{~d}$ for the pistillate inflorescence as a whole (Pjatniski, 1947; in Rushton, 1977). Stigma receptivity for a given tree was found to be roughly 15 days in $Q$ ilex $L$ (Lumaret et al, 1991). In annual acorns, eg in the white oaks section of the genus, meiosis and fertilization of ovules occur 1 or 2 months after pollen deposition. In biennial acorns, eg in most of the American red oak section, the delay is about 13-15 months (Helmqvist, 1953; Arena, 1958; Sharp, 1958; Corti, 1959; Stairs, 1964; Brown and Mogensen, 1972). In several species, such as $Q$ coccifera $L$ and $Q$ suber $L$, annual and biennial, or even intermediate acorns, occur on distinct individual trees (Corti, 1955; Bianco and Schirone, 1985). One embryo sac is usually initiated per spore and this develops in the nucellus. Rare cases of polyembryony, due to the development of more than 1 embryo sac per nucellus, or to the occurrence of 2 nucelli per ovule, have been reported (Helmqvist, 1953; Corti, 1959; Stairs, 1964). At fertilization, the pollen tube enters the ovule through the micropyle (Helmqvist, 1953) after which 1 of the 6 ovules in the ovary develops into a seed. This ovular dominance occurs during early embryo growth (Stairs, 1964). Mogensen (1975) reported that 4 types of abortive ovules occur in $Q$ gambelii Nutt, with an average of 2.7 ovules per ovary that do not develop into seed due to lack of fertilization. In other cases, ovule abortion was due to zygote or embryo failure, or the absence of an embryo sac or the occurrence of an empty one. For these reasons, Mogensen (1975) proposed that the first fertilized ovule either suppresses the growth of the other fertilized ovules or prevents their fertilization. After fertilization, the acorns mature within about 3 months, then fall (Sharp, 1958; Corti, 1959). Each year, even when a good acorn crop occurs, a large amount ( $70 \%$ or more) of fruit abscisses (Williamson, 1966; Feret et al, 1982).

The occurrence of a period of stigma receptivity longer than the period of pollen production for an individual tree may diversify the number of potential partners for a given tree (Lumaret et al, 1991).

\section{Life cycle}

\section{Life span and vegetative multiplication}

Several species which possess vegetative multiplication produce rejuvenated stems from root crown, trunk or rhizomes, so that it becomes impossible to ascertain the age of a given individual. It is, nevertheless, likely that such oaks are long-lived species (Stebbins, 1950; Muller, 1951). For example, $Q$ ilicifolia Wangenh and $Q$ hinckleyi Muller have short-lived stems (20-30 yr and 7-9 yr respectively) but they mainly reproduce via sprouts (Muller, 1951; Wolgast and Zeide, 1983). This capacity for stump sprouting may be present in juveniles and, although decreasing with the age of the trunk, may enable oaks to maintain their populations even in the absence of acorn production (Muller, 1951; Jones, 1959; Neilson and Wullstein, 1980; Andersson, 1991).

\section{Age and reproduction}

The age of first acorn production varies with the species, but also with latitude, life span, tree density (a low density favors earlier reproductive maturity) and site 
(Sharp, 1958; Jones, 1959; Shaw, 1974). The age of first reproduction also occurs earlier for trees in coppiced sites than those from seed origin, and range from 3 growing seasons old for the short-lived sprouts of $Q$ ilicifolia (Wolgast and Stout, $1977 \mathrm{~b})$ to $30-45$ years for the long-lived species $Q$ petraea (Matt) Liebl (Jones, 1959). Acorn yield is often correlated with tree size, although, fecundity decreases with increasing diameter (Sharp, 1958; Iketake et al, 1988).

\section{Sex allocation}

As oaks are monoecious, individual trees may show biased reproductive effort favoring one or the other of the sexes. Variability in flowering abundance among trees within the same year has been reported for $Q$ alba $L$ (Sharp and Chisman, 1961; Feret et al, 1982), $Q$ acuta Thumb (Iketake et al, 1988), $Q$ pedunculiflora C Koch (Enescu and Enescu, 1966), $Q$ ilex (Lumaret et al, 1991) and $Q$ ilicifolia (Aizen and Kenigsten, 1990). Between-year variation in flower abundance for a given tree, eg variation in catkin density in $Q$ cerris $L$ and $Q$ ilex, has also been reported (Hails and Crawley, 1991; Lumaret et al, 1991). In the latter case, variation in male and female investment concerned $15-20 \%$ of the individuals.

\section{Acorn production by individual trees}

Variation in acorn production among individual trees has been well documented and appears to be a general rule in oak species. In each year of a 14-year study on Quercus alba, massive variation in acorn yield was observed among the trees (Sharp and Sprague, 1967). In Q ilicifolia, Wolgast (1978b) found, for a given year, interindividual variation in the production of immature acorns by trees growing in the same stand to be greater than stand-tostand or site-to-site variation. Many other similar examples have been reported (eg Jones, 1959; Feret et al, 1982; Hunter and Van Doren, 1982; Forester, 1990; Hails and Crawley, 1991).

For interannual variation, Forester (1990) and Hails and Crawley (1991) have observed that fruit set in $Q$ robur $L$ is mainly a characteristic of individual trees. Similarly, Sharp (1958) has reported that, in white oaks, each tree is fairly consistent in acorn production, at least in years of good acorn crops. In addition, for $Q$ ilicifolia individuals transplanted to a common site, individuals of different origins were not found to have the same productivity (Wolgast, 1978a). In $Q$ pedunculifiora (Enescu and Enescu, 1966) and $Q$ alba (Farmer, 1981), substantial clonal control over seed yield has been reported. However, in several species of the red oak section, acorn production can fluctuate widely for a single tree over a number of years (Sharp, 1958; Grisez, 1975).

\section{Mean acorn production at single sites}

For single sites as a whole, a consistent abundance of flowers from year to year is usually observed, in marked contrast to the marked fluctuations in acorn production known to occur (Sharp and Sprague, 1967; Grisez, 1975; Hails and Crawley, 1991). The occurrence of mast years in acorn production seems to depend upon many factors and is a problem that remains distinct from the interannual variation in seed production that occurs for individual trees. Thus, in red-oak populations, acorn crops can be consistent from one year to the next, because of variation between individuals each year and variation within individuals between years (Sharp, 1958; Grisez, 1975). Because each year's flowers are initiated independently of the environmen- 
tal fluctuations occurring during flowering the next spring (Bonnet-Masimbert, 1978; Crawley, 1985), there is some unpredictability in fruit set. It will depend upon the success of pollination and compatibility of male and female gametes (Farmer, 1981; Stephenson, 1981; Sutherland, 1986), on the amount of resources and water available at the time of flowering and fruiting (Corti, 1959; Sharp and Chisman, 1961; Wolgast and Stout, 1977a), and will be susceptible to many environmental conditions, such as soil fertility (Wolgast and Stout, 1977b), attack by parasites and weather cues (Wood, 1938; BonnetMasimbert, 1973; Neilson and Wullstein, 1980; Feret et al, 1982; Crawley, 1983).

Two strategies have thus been described for oaks. In the long-lived species $Q$ robur, Crawley (1985) has found that trees initially allocate resources to vegetative development, and once survival has been ensured, commence acorn development. In the short-lived $Q$ ilicifolia, Wolgast and Zeide (1983) have shown that, at the juvenile stage, environmental stress which is not too severe can increase seed production, whereas good conditions tend to augment vegetative growth. In $Q$ ilex and $Q$ pubescens, acorns have been found to be lighter in years of low production (Bran et al, 1990). A further explanation for between-year variation in acorn production is that the trees have an "interval clock" (Sharp, 1958; Sharp and Sprague, 1967; Feret et al, 1982; Forester, 1990). The occurrence of unpredictable mast-fruiting years may also control populations of seed predators (Forester, 1990; Smith et al, 1990). Several examples of variation in the population dynamics of acorn parasites are known in relationship to the abundance of fruit production (eg Smith KG, 1986a,b; Smith KG and Scarlett, 1987; Hails and Crawley, 1991). Relationships have also been demonstrated between acorn size and their dispersal ability, their tolerance to parasite attacks and the vigor of young seedlings (McComb, 1934; Jarvis, 1963; Fry and Vaughn, 1977; Aizen and Patterson, 1990; Forester, 1990; Scarlett and Smith, 1991).

\section{Breeding system}

\section{Incompatibility within and between species}

From both direct experimental tests of selfpollination and crosses between half-sibs (Lumaret et al, 1991; Kremer and Daubrée, 1993) and indirect estimates of outcrossing rates from electrophoretic data (Yacine and Lumaret, 1988; Aas, 1991; Schwartzmann, 1991; Bacilieri et al, 1993; Kremer and Daubrée, 1993), it has been shown that oak species are highly selfincompatible. Hagman (1975) has stated that, in oaks, this incompatibility is due to a gametophytic control of the pollen-tube growth in the style. Interspecific crosses are not rare within the same systematic section and several cases of hybridization between sections have been reported (Cornuz, 1955-1956; Van Valen, 1976). Dengler (1941; in Rushton, 1977) and Rushton (1977) have shown that controlled crosses between $Q$ robur and $Q$ petraea may be successful but with variation according to the year.

\section{Phenology}

Oak trees flower during the spring in temperate regions and during the dry season in paleotropical areas (Sharp, 1958; Shaw, 1974; Kaul et al, 1986). It has been shown in Spain that up to $85 \%$ of $Q$ ilex trees have a second flowering period during late spring or autumn (Vasquez et al, 1990). Only a few studies of individual tree phenology have been completed. They have 
shown: 1) that, among the trees of a given location, perfect synchronization from bud opening to the flowering stage does not occur; and 2) that interannual variation in flowering time may involve up to $30 \%$ of the individuals (Sharp and Chisman, 1961; Rushton, 1977; Fraval, 1986; Du Merle, 1988; Lumaret et al, 1991).

The success of natural crosses ultimately depends upon synchronization in flowering phenology between trees and the pattern of resource allocation to reproductive functions. In addition, there are no stable reproductive groups of individuals from one year to the next which could lead to homogamy. Such characteristics lead to a diversification of the effective pollen cloud received by each tree for a given year, and for a single tree in different years (Copes and Sniezko, 1991; Lumaret et al, 1991).

\section{GENE FLOW}

Levin and Kerster (1974) have defined 'potential gene flow' as the deposition of pollen and seeds from a source according to the distance. In contrast, 'actual gene flow' refers to the incidence of fertilization and establishment of reproductive individuals as a function of the distance from the source. The potential gene flow is a measure of physical dispersal, whereas to measure actual gene flow, appropriate genetic markers, eg isozymes and restriction fragment length polymorphism are required.

\section{The physical dispersal (potential gene flow)}

The variance in parent-offspring dispersal distribution $\left(\sigma^{2}\right)$ has been separated into its different components by Crawford (1984) and Gliddon et al (1987). These au- thors consider this parent-offspring dispersal as consisting of 2 distinct phases, ie gametic and zygotic dispersal. In plant species which show significant amounts of vegetative growth, it is necessary to consider this growth as a component of dispersal. Combining these several components Gliddon et al (1987) have proposed the following formula:

$$
\sigma^{2}=\frac{\mathrm{t}}{2} \sigma_{\mathrm{p}}^{2}+\sigma_{\mathrm{v}}^{2}+\sigma_{\mathrm{s}}^{2}
$$

where $t$ is the proportion of pollen and/or ovules outcrossed, $\sigma_{\mathrm{p}}^{2}$ is the variance in pollen dispersal from flower to flower, $\sigma_{v}^{2}$ is the variance in dispersal of flowers from the plant base and $\sigma_{\mathrm{s}}^{2}$ is the seed dispersal variance from the flower to the site of seed germination. Each of these dispersal components is reviewed below.

\section{Pollen dispersal}

Little information exists concerning oakpollen dispersal. The velocity of pollengrain movement is negatively correlated with grain diameter (McCubbin, 1944; Levin and Kerster, 1974). Oak species have relatively small pollen grains (Olsson, 1975; Rushton, 1976; Solomon, 1983a,b). Niklas (1985) has shown that a higher release point allows more horizontal movement. The pollen dispersal parameters calculated for several species in table I show that the oak species ( $Q$ robur) has a relatively high pollen-dispersal potential. The local-mate-competition model developed by Lloyd and Bawa (1984) and Burd and Allen (1988) predicts that taller individuals reduce local-mate competition and have less saturating fitness curves due to a wider dispersal of their pollen and a higher male investment. All these models predict a large dispersal distance for the main oak species (Quercus petraea, $Q$ alba, $Q$ rubra, etc) and a relatively low 
Table I. Weight, size, velocity and distance of pollen dispersal according to the model of Dyakowska and Zurzycki (1959).

\begin{tabular}{lllll}
\hline Species & $W$ & $S$ & $V$ & $D$ \\
\hline
\end{tabular}

$\begin{array}{lrccr}\text { Dactylis glomerata } & 1.9 & 33.3 & 3.1 & 174.2 \\ \text { Picea abies } & 93.2 & 162 & 6.8 & 22.2 \\ \text { Pinus sylvestris } & 30.1 & 59 & 3.7 & 267.8 \\ \text { Alnus sp } & 9.4 & 24.6 & 2.8 & 546.7 \\ \text { Coryllus avellana } & 9.5 & 24.2 & 2.9 & 267.8 \\ \text { Quercus robur } & 18.1 & 24.8 & 4 & 199.0\end{array}$

W: weight in $10^{-9} \mathrm{~g}$; : size in $\mu \mathrm{m}$; $\mathrm{V}$ : velocity in $\mathrm{cm}^{-1} \mathrm{~s}^{-1}$; $\mathrm{D}$ : distance in $\mathrm{km}$.

pollen dispersal for the small species $(Q$ inkleyi).

Several factors may act to reduce pollen dispersal, eg a high vegetation density, precipitation and leaf cover (Tauber, 1977). Except for the evergreen oaks, flowering begins prior to leaf expansion. Dispersal over short distances depends upon pollen production which is very variable and, in contrast, is constant for long distance (Tauber, 1977). All this information predicts a variable and high pollendispersal potential.

\section{Seed dispersal}

Seed dispersal is easier to observe than pollen dispersal and has thus been the subject of much research by scientists in many different disciplines (eg plant geneticists, plant biologists, animal behaviorists). The possession of acorns, ie heavy nuts dispersed by gravity, has led to the suggestion that oaks are K-selected species with low mobility (Harper et al, 1970). In the absence of biotic dispersal vectors, large seeds, such as acorns, move shorter distances than smaller ones (Salisbury,
1942; Harper et al, 1970). However, the rapid post-glacial migration of oak species has raised questions concerning how acorns are actually dispersed, since it has frequently been observed that distances of up to $300 \mathrm{~m}$ per year may occur (Skellam, 1951; Gleason and Cronquist, 1964; Webb, 1966; Johnson and Webb, 1989). The minimum seed-dispersal distances necessary for such range extension are equal to $7 \mathrm{~km} /$ generation (Webb, 1986). Mammals and birds which eat and thereby disperse acorns vary in their caching behavior: thus transport distance is highly variable.

In North America, at least 90 species of mammals are involved in acorn predation and dispersal (Van Dersal, 1940). These mammals are comprised of 2 groups, each of which has contrasting roles in acorn utilization and dispersal. First are the small mammals (eg mice, voles, squirrels and gophers), which trap food locally, and the larger non-caching animals (eg deer, hare, wild boar and bear). Mice are known to move acorns only over tens of metres from the source trees (Orsini, 1979; Sork, 1984; Jensen and Nielsen, 1986; Miayaki and Kikuzawa, 1988). Rodents appear to be the most important seed predators (Mellanby, 1967; Vincent, 1977; Vuillemin, 1978; Orsini, 1979; Jensen, 1982; Kikuzawa, 1988) and can reduce the effect of dispersal (Jensen and Nielsen, 1986). Seeddispersal distances for squirrels may be several times larger, reaching $150 \mathrm{~m}$ for seeds of Juglans nigra dispersed by Sciurus niger (Stapanian and Smith, 1978), but is often less than $40 \mathrm{~m}$. The habit of embryo excision in white oaks limits seed dispersal compared to the red oak (Wood, 1938; Fox, 1982).

The second category of animals moves acorns greater distances but destroys the ones they eat. Birds that feed on acorns fall into 3 groups: 1) those which do not cache acorns and destroy them (turkeys, ducks, pheasants, pigeons); 2) those 
which disperse and cache acorns above the ground (woodpeckers, parids, nuthatches); and 3) birds which routinely cache acorns in the soil. The first 2 groups offer virtually no opportunity for effective dispersal, although a very small number of seeds may be dispersed by these birds (Webb, 1986). The third group appears to be exclusively made up of the American and European jays. Recent research on these birds (Bossema, 1979; Darley-Hill and Johnson, 1981; Johnson and Adkisson, 1985, 1986; Johnson and Webb, 1989) provide new insight into longdistance dispersal of oaks and may help explain the patterns of vegetation-climate equilibria observed to occur after the last glaciation. Darley-Hill and Johnson (1981) found for the blue jay that the mean distance between maternal trees and their seed deposition sites was $1.1 \mathrm{~km}$ with a range of $100 \mathrm{~m}$ to $1.9 \mathrm{~km}$ and which could reach $5 \mathrm{~km}$ (Johnson and Paterson: in Darley-Hill and Johnson, 1981). Nuts were dispersed individually within a few meters of each other and were always covered with debris or soil. Covering improved germination, rooting and early growth by protecting the acorns and the radicle from desiccation and solar insulation, and scatter hoarding decreased the concentration of seeds under the parental trees and thus reduced the probability that the seeds would be eaten by other predators (Griffin, 1970; Barnett, 1977; Bossema, 1979; Forester, 1990). The occurrence of numerous oak seedlings in jay hoarding sites and the tendency for jays to hide acorns in open environments improves the chance of survival and indicates that jays facilitate the colonization of open area by oaks. Bossema (1979) concluded that for several reasons, jays and oaks can be considered as co-adapted features of symbiotic relationship.

The oak forest settlement could occur in 2 phases: 1) the arrival of colonizers fol- lowing long-distance dispersal by jays; 2) population settlement following shortdistance dispersal by small mammals and jays.

\section{Vegetative dispersal}

Vegetative dispersal in the genus Quercus can occur in two ways (Muller, 1951). The first is stump sprouting. This phenomenon is very common among oak species (eg, Quercus rubra, $Q$ virginiana and $Q$ ilex). The second is rhizomatous sprouting, different types of which have been described depending upon: 1) rhizome length: from 4-20 cm for short rhizomes (Quercus hinckleyi) and from $0.3 \mathrm{~m}$ to $>1 \mathrm{~m}$ for long rhizomes ( $Q$ havardii); and 2) the origin of the rhizomes, which may either be juvenile rhizomes (terminating in a tree-habit, 1-6 $m$ in $Q$ virginiana) or rhizomes from mature trees ( $Q$ toza or $Q$ ilex).

Even with a short rhizome, an individual can cover large areas (3-15 $\mathrm{m}$ in diameter) due to prolific sprout production.

In contrast to pollen and acorn dispersal, vegetative propagation is not an important component of gene flow. It can, however, participate in the maintenance of genetic variability within a population (Lumaret et al, 1991).

\section{Theoretical approach (actual gene flow)}

For most species, the actual movement of genes has been observed to occur over distances much smaller than those determined according to the mobility of these genes; second, a strong natural selection can overcome the homogenizing effects of gene flow and can produce local differentiation (McNeilly and Antonovics, 1968).

Several indirect approaches are available to assess actual gene flow: 1) the correlation between variables at different spa- 
tial locations (Moran's index) which measures the genetic structuration within a population and is independent of any assumption regarding population structure; 2) Wright's fixation index, $F_{\text {is }}$ and its derivatives. $F$ statistic quantifies the deviation of the observed genotypic structure from hardy-Weinberg proportions in terms of the heterozygote deficiency within a population for the $F_{i s}$ and between populations for the $F_{s t}$ and gives an estimation of genetic structuration. A deviation of the $F_{\text {is }}$ from this expected value can be caused by the combined effects of random drift, selection, mating system, founder effects, assortative mating and the Wahlund effect. $N_{m}$ which is the mean number of migrants exchanged among populations is calculated using the following formula (Slatkin, 1987): $N_{m}=\left(1 / F_{s t}-1\right) / 4,\left(G_{s t}=F_{s t}\right)$.

As indicated in table II, Wright's fixation index calculated by using enzyme markers, indicates a situation close to random mating for Quercus ilex (Yacine and Lumaret, 1989) and Quercus rubra (Schwarzmann, 1991) or a slight deficit of heterozy- gotes for $Q$ macrocarpa and $Q$ gambelii (Schnabel and Hamrick, 1990) $Q$ rubra (Sork et al, in press) and $Q$ agrifolia, $Q$ lobata and $Q$ douglasii (Millar et al, in press). This observed deficit of heterozygotes could not be explained by the selfing rate which is very low for all the studied species. This result has been explained by: 1 ) structuration within a stand (Sork et al, 1993) which induces Wahlund's effect; and 2) assortative mating (Rice, 1984).

As indicated in table III, gene flow between populations or between different species of oak is greater than that observed between populations of many other plant species (Govindaraju, 1988) and limits the possibility of differentiation because the number of migrants $\left(N_{m}\right)$ is greater than one (Levin and Kerster, 1974). For the nuclear genome, the observed differentiation among populations is weak (Yacine and Lumaret, 1989; Schnabel and Hamrick, 1990; Kremer et al, 1991; MüllerStarck and Ziehe, 1991; Schwarzmann, 1991; Millar et al, in press; Sork et al, 1993). The strong structuration obtained

Table II. $\boldsymbol{F}_{\text {is }}$ data for different oak species.

\begin{tabular}{lrrrl}
\hline Species & \multicolumn{1}{c}{$\mathrm{F}_{\text {is }}$} & No of pop & No of loci & Ref \\
\hline Q ilex & -0.008 & 16 & 3 & Yacine and Lumaret (1989) \\
Q rubra & -0.008 & 8 & 13 & Schwarzmann (1991) \\
Q macrocarpa & 0.026 & 21 & 26 & Schnabel and Hamrick (1990) \\
Q gambelii & 0.014 & 4 & 24 & \\
Q agrifolia & 0.087 & 15 & 12 & Millar et al (in press) \\
Q lobata & 0.098 & 7 & 15 & \\
Q douglasii & 0.108 & 7 & 15 & \\
Q rubra & 0.128 & 11 & 14 & Sork et al (1993) \\
Northern pop & 0.202 & 4 & 12 & \\
Southern pop & 0.077 & 7 & 12 & \\
& & & & \\
\hline
\end{tabular}

\footnotetext{
a pop $=$ population
} 
Table III. Number of migrants per generation $\left(N_{m}\right)$ among populations (pop) and between species in several oak species. The review is based on studies using nuclear markers (nucl) with biparental inheritance (eg, isozymes) and chloroplastic DNA (cp DNA) with maternal inheritance.

\begin{tabular}{|c|c|c|c|}
\hline Species & $\mathrm{N}_{\mathrm{m}}$ & Marker & Reference \\
\hline $\begin{array}{c}\text { Intra-specific } \\
\text { Q rubra }\end{array}$ & 27 & Nucl & Schwarzmann (1991) \\
\hline Q ilex & 3.17 & Nucl & Yacine and Lumaret (1989) \\
\hline $\begin{array}{l}Q \text { macrocarpa } \\
Q \text { gambelii }\end{array}$ & $\begin{array}{l}3.03 \\
1.85\end{array}$ & $\begin{array}{l}\text { Nucl } \\
\mathrm{Nucl}\end{array}$ & Schnabel and Hamrick (1990) \\
\hline $\begin{array}{l}Q \text { agrifolia } \\
Q \text { lobata } \\
Q \text { douglasii }\end{array}$ & $\begin{array}{r}3 \\
8 \\
25\end{array}$ & $\begin{array}{l}\text { Nucl } \\
\text { Nucl } \\
\text { Nucl }\end{array}$ & Millar et al (in press) \\
\hline $\begin{array}{l}\text { Q rubra } \\
\text { Northern pop } \\
\text { Southern pop }\end{array}$ & $\begin{array}{l}2.99 \\
1.07\end{array}$ & $\begin{array}{l}\text { Nucl } \\
\text { Nucl }\end{array}$ & Sork et al (1993) \\
\hline$Q$ petraea & 10.60 & Nucl & Kremer et al (1991) \\
\hline $\begin{array}{l}\text { Interspecific } \\
\text { Q rubra 'complex' }\end{array}$ & 2.65 & Nucl & Manos and Fairbrother (1987) \\
\hline Q alba 'complex' & 0.48 & cp DNA & Whittemore and Schaal (1991) \\
\hline$Q$ petraea and $Q$ robur & 2.62 & Nucl & Kremer et al (1991) \\
\hline
\end{tabular}

by the chloroplast DNA (Whittemore and Schaal, 1991) and the low structuration observed by isozymes supports the fact that seeds are less mobile than pollen.

Chloroplast DNA variation in oaks does not reflect the species boundaries, but is concordant with the geographical location of the population. These results suggest that genes are exchanged between species, even between pairs of species that are distantly related and show limited ability to hybridize. The genotypes distributed in American (Whittemore and Schaal, 1991) and European (Kremer et al, 1991) oaks are thus not part of a completely isolated gene pool, but are actively exchanging genes.
The conclusion obtained from estimating the potential gene flow, ie that the gene flow is very high within and even between oak species, is thus further confirmed by assessment of the actual gene flow.

\section{DISCUSSION}

The life history traits of oak species (mating system, phenology, wind pollination, jay-oak co-evolution, incompatibility, sex allocation, acorn production and life span) lead to significant gene flows. This phenomenon is confirmed by the molecular markers which give the highest values obtained in the plant world. 
Species occupying disturbed or transient habitats usually have a greater dispersability than those in more advanced or stable habitats (Levin and Kerster, 1974). This generality appears to hold for different oak species. For example, if we compare Quercus robur and $Q$ petraea, it can be seen that in the former, physiological characters such as a high light requirement (Jones, 1959; Horn, 1975; Wigston, 1975; Duhamel, 1984) high pollen dispersal due to small pollen diameter, and wide acorn dispersal due to their being the European jay's preferred food (Bossema, 1979), convey a high colonizing ability. $Q$ petraea, however, is the species which is more commonly found in climax communities due to its shade tolerance and its ability to replace $Q$ robur during successional forest development (Rameau, 1987).

During its lifetime, a population passes through different stages: colonization, establishment, succession and extinction. Although one local population may thus be in disequilibrium, the collection of local populations (ie a metapopulation) may be at equilibrium (Levins, 1971; Olivieri et al, 1990). During these phases, the interand intrapopulation gene-flow intensity and pattern varies (Thiébaut et al, 1990). First, during the colonization stage, the trees are scattered and the pollen (Tauber, 1977) and acorns travel over large distances (Bossema, 1979; Darley-Hill and Johnson, 1981). The slight differentiation observed in the northern populations of $Q$ rubra (Sork et al, 1993) confirms this because since the last glaciation, the number of generations has been low and structuration has not yet had time to develop. Second, during the later stages, pollen and seed dispersal are low and differentiation is more marked. The southern populations of red oak, where the number of generations is higher, show such a pattern.
The concept of a biological species advocated by Mayr $(1942,1963)$ as a group of organisms that are actually or potentially interbreeding is not applicable to the genus Quercus because it relies on a total isolation between species. Using morphological, ecological or physiological characters, several authors (Burger, 1975; Hardin, 1975; Van Valen, 1976) have discussed this problem. A model more appropriate to oaks is that which considers species as adaptative peaks, in which interspecific gene flow is balanced by selection for one or several groups of co-adapted and linked alleles (Whittemore and Schaal, 1991). This theory could explain how sympatric species are able to remain distinct despite considerable gene exchange.

The pattern of gene flow, the assessment of selection pressure and the demography of natural populations could be used to determine the limits and the amplitude of seed-collection zones and genetic resource reserves. Slatkin (1978) has developed a model which Govindaraju (1990) has applied to 2 species of pine. Such a model could also be used for the different oak species.

Falk (1990) suggests that the loss of dispersability (ie gene flow) could induce the decline of a species and may explain the situation of several endangered oak species ( $Q$ inckleyi, $Q$ tardifolia). On the contrary, maintaining gene flow mainly improves the chance of survival for species facing habitat fragmentation (deforestation, urbanization) and global change. The activity of jays in transporting and hoarding acorns provides one hopeful sign that the main oak species may be able to shift location relatively quickly.

\section{ACKNOWLEDGMENT}

We thank $\operatorname{Dr} \mathrm{J}$ Thomson for useful comments on the manuscript. 


\section{REFERENCES}

Aas G (1991) Kreuzungsversuche mit Stiel- und Traubeneichen (Quercus robur $\mathrm{L}$ und $Q$ petraea (Matt) Liebl). Allg Forst Jagdztg 162, 141-145

Aizen MA, Kenigsten A (1990) Floral sex ratios in scrub oak (Quercus ilicifolia) vary with microtopography and stem height. Can $J$ Bot $68,1364-1368$

Aizen MA, Patterson WA (1990) Acorn size and geographical range in the North American oaks (Quercus L). J Biogeogr 17, 327-332

Andersson C (1991) Distribution of seedlings and saplings of Quercus robur in a grazed deciduous forest. J Veg Sci 2, 279-282

Arena M (1958) Ricerche sul ciclo riprodittivo di specie del genere Quercus della flora italiana. III. Contributo alla biologia di Quercus pubescens Willd in Sicilia. Ann Accad Ital Sci For 7, 259-289

Bacilieri R, Roussel G, Ducousso A (1993) Hybridization and mating system in a mixed oak stand of sessile and pedunculate oak. Ann Sci For 50 (suppl 1), 122s-127s

Barnett RJ (1977) The effect of burial on germination and survival of oak hickory nuts. $A m$ Midl Nat 98, 319-330

Bianco P, Schirone B (1985) On Quercus coccifera $\mathrm{L} \mathrm{sl}$ : variation in reproductive phenology. Taxon $34,436-439$

Bonnet Masimbert M (1973) Problème de l'irrégularité des glandées : peut-être un aspect entomologique? Rev For Fr 25, 375377

Bonnet-Masimbert M (1978) Biologie florale des chênes pédonculés et sessiles (Quercus pedunculata Ehrh et $Q$ sessiliflora Sal). In: Symp, Régénération et le Traitement des Forêts Feuillues de Qualité en Zone Tempérée. CNRF, 11-15 Sept 1978, Champenoux, 1729

Bossema I (1979) Jays and oaks: an ecological study of a symbiosis. Behaviour 70, 1-118

Bran D, Lobréaux $O$, Maistre $M$, Perret $P$, Romane F (1990) Germination of Quercus ilex and $Q$ pubescens in a $Q$ ilex coppice. Long-term consequences. Vegetatio 87 , 45-50
Brett DW (1964) The inflorescence of Fagus and Castanea, and the evolution of cupules of the Fagaceae. New Phytol 63, 96-118

Brown RC, Mogensen HL (1972) Late ovule and early embryo development in Quercus gambelii. Am J Bot 59, 311-316

Burd M, Allen TFH (1988) Sexual allocation strategy in wind-pollinated plants. Evolution 42, 403-407

Burger WC (1975) The species concept in Quercus. Taxon $24,45-50$

Copes DL, Sniezko RA (1991) The influence of floral bud phenology on the potential mating system of a wind-pollinated Douglas-fir orchard. Can J For Res 21, 813-820

Cornuz L (1955-1956) Un cas intéressant d'hybridité du Chêne vert. Schweiz Beitr Dendrol 6, 23-25

Corti R (1955) Ricerche sul ciclo riprodittivo di specie del genere Quercus della flora italiana. II. Contributo alla biologia ed alla sistematica di Quercus suber $L$ e in particolare delle forme a sviluppo biennale della ghianda. Ann Accad Ital Sci For 4, 55-136

Corti R (1959) Ricerche sul ciclo riprodittivo di species del genere Quercus della flora italiana. IV. Osservazioni sulla embriologia e sul ciclo riproduttivo in Quercus ilex L. Ann Accad Ital Sci For 8, 19-42

Crawford TJ (1984) The estimation of neighbourhood parameters for plant populations. Heredity 52, 273-283

Crawley MJ (1983) Herbivory. The Dynamics of Animal-Plant Interactions. Blackwell Sci Publ, Oxford

Crawley MJ (1985) Reduction of oak fecundity by low-density herbivore populations. Nature (Lond) 314, 163-164

Darley-Hill S, Johnson W (1981) Acorn dispersal by the blue jay (Cyanocitta cristata). Oecologia $50,231-232$

Dengler A (1941) Bericht über Kreuzungsversuche zwischen Trauben und Stieleiche und zwischen europäischer und japanischer Lärche. Mitteilungen der H Göring-Akademie der deutschen Forstwissenschaft 1, 87-109

Du Merle P (1988) Phenological resistance of oaks to the green oak leafroller, Tortrix viridana L. (Lep Tortricidae). In: Mechanisms of Woody Plant Defences Against Insects: Search for Pattern (Mattson WJ, Levieux J, 
Bernard-Dagan C, eds) Springer Verlag, Berlin, 215-226

Duhamel D (1984) Statut écologique du chêne pédonculé et du chêne sessile dans le quart nord-ouest de la France. ENITEF, Thesis, Nogent-sur-Vernisson, France

Dyakowska J, Zurzycki J (1959) Botany: gravimetric studies on pollen. Bull Acad Pol Sci Ser Sci Biol 2, 7-16

Enescu V, Enescu V (1966) Floraison de quelques clones de Quercus pedunculiflora C Koch. Rev Padurilor 1, 1-8

Falk DA (1990) Endangered forest resources in the US: integrated strategies for conservation of rare species and genetic diversity. For Ecol Manage 35, 91-117

Farmer RE Jr (1981) Variation in seed yield of white oak. For Sci 27, 377-380

Feret PP, Kreh RE, Merkle SA, Oderwald RG (1982) Flower abundance, premature acorn abscission and acorn production in Quercus alba L. Bot Gaz 143, 216-218

Forester GJ (1990) The population ecology of acorn weevils and their influence on natural regeneration of oak. PhD thesis, Univ London

Fox JF (1982) Adaptation of grey squirrel behaviour to autumn germination of white oak acorns. Evolution 36, 800-809

Fraval A (1986) Observations sur la phénologie du chêne-liège, arbre nourricier du bombyx disparate en forêt de la Mamora (Maroc). Doc Dept Zool Inst Agron Vét Hassan II Rabat $86,1-28$

Fry ME, Vaughn CE (1977) Acorn selection by band-tailed pigeons. Calif Dep Fish Game Bull 63, 59-60

Gleason HA, Cronquist A (1964) The Natural Geography of Plants. Columbia Univ Press, New York

Gliddon C, Belhassen E, Gouyon PH (1987) Genetic neighbourhoods in plants with diverse systems of mating and different patterns of growth. Heredity 59, 29-32

Govindaraju DR (1988) Relationship between dispersal ability and levels of gene flow in plants. Oikos 59, 31-35

Govindaraju DR (1990) Gene flow spatial patterns and seed-collection zones. For Ecol Manage 35, 291-302
Griffin JR (1970) Oak regeneration in the upper Carmel valley, California. Ecology 52, 862.868

Hagman M (1975) Incompatibility in forest trees. Proc R Soc Lond Ser B 188, 313-326

Hails RS, Crawley MJ (1991) The population dynamics of an alien insect: Andricus quercuscalicis (Hymenoptera: Cynipidae). J Anim Ecol 60, 545-562

Hardin JW (1975) Hybridization and introgression in Quercus alba. J Arnold Arbor 56, 336363

Harper JI, Lovell PH, Moore KG (1970) The shapes and sizes of seeds. Annu Rev Ecol Syst 1, 327-356

Helmqvist $H$ (1953) The embryo sac development of Quercus robur L. Phytomorphology 3, 377-384

Horn HS (1975) Markovian process of forest succession. In: Ecology and Evolution of Communities (Cody ML, Diamonds JM, eds) Blackwell Sci Publ, Oxford, 196-213

Hunter SC, Van Doren R (1982) Variation in acorn and seedling characteristics of two California oaks. Gen Tech Rep PSW-58. Berkeley CA: US For Serv Pac SW For Range Exp Stn, 606

Iketake N, Okitu S, Takahashi K (1988) Femaleflower production of Quercus acuta Thunb in secondary evergreen broad-leaved forest. Tech Bull Fac Hort Chiba Univ 41, 121-125

Jarvis PG (1963) The effects of acorn size and provenance on the growth of seedlings of sessile oak. $Q J$ For $57,11-19$

Jensen TS (1982) Seed production and outbreaks of non-cyclic rodent populations in deciduous forests. Oecologia 54, 184-192

Jensen TS, Nieisen OF (1986) Rodents as seed dispersers in a heath-oak wood succession. Oecologia 70, 214-221

Johnson WC, Adkisson CS (1985) Dispersal of beech nuts by the blue jays in fragmented landscapes. Am Midl Nat 113, 319-324

Johnson WC, Adkisson CS (1986) Airlifting the oaks. Nat Hist 95, 40-47

Johnson WC, Webb T (1989) The role of blue jays (Cyanocitta cristata $L$ ) in the post glacial dispersal of fagaceous trees in eastern north America. J Biogeogr 16, 561-571

Jones EW (1959) Biological flora of the British Isles, Quercus L. J Ecol 47, 160-222 
Kaul RB, Abbe EC, Abbe LB (1986) Reproductive phenology of the oak family (Fagaceae) in the lowland rain forests of Borneo. Biotropica 18, 51-55

Kikuzawa K (1988) Dispersal of Quercus mongolica acorns in a broadleaved deciduous forest. 1. Disapearance. For Ecol Manage $25,1-8$

Kremer A, Daubrée JB (1993) Reproduction sexuée en forêt : régime de reproduction et flux génique. In: Monographie du Chêne Rouge (Timbal J, ed) INRA, Paris (in press)

Kremer A, Petit RJ, Zanetto A, Fougère V, Ducousso A, Wagner D (1991) Nuclear and organelle gene diversity in Quercus robur and $Q$ petrae. In: Genetic Variation of Forest Tree Populations in Europe (Ziehe M, MüllerStark G, eds) Sauerländer-Verlag, Berlin 151-166

Levin DA, Kerster HW (1974) Gene flow in seed plants. Evol Biol 7, 139-220

Levins R (1971) Evolution in Changing Environments. Princeton Univ Press, Princeton, $\mathrm{NJ}$, 2nd edn

Lloyd DG, Waba KS (1984) Modification of the gender of seed plants in varying conditions. Evol Biol 17, 255-338

Loveless MD, Hamrick JL (1984) Ecological determinants of genetic structure in plant populations. Annu Rev Ecol Syst 15, 65-95

Lumaret $\mathrm{R}$, Yacine A, Berrod A, Romane $\mathrm{F}, \mathrm{Li}$ TX (1991) Mating system and genetic diversity in holm oak (Quercus ilex L Fagaceae). In: Biochemical Markers in the Population Genetics of Forest Trees (Fineschi S, Malvolti ME, Cannata F, Hattemer $\mathrm{HH}$, eds) SPB Academic Publ, The Hague, 149-153

Manos PS, Fairbrothers DE (1987) Allozyme variation in populations of six northeastern American red oaks (Fagaceae: Quercus subg Erythrobalanus). Syst Bot 12, 365-373

Mayr E (1942) Systematics and the Origin of Species. Columbia Univ Press, New York

Mayr E (1963) Animal Species and Evolution. Harvard Univ Press, Cambridge, MA

McComb AL (1934) The relation between acorn weight and the development of one year chesnut oak seedlings. J For 1, 479-484

McCubbin WA (1944) Relation of spore dimensions to their rate fall. Phytopathology 34 230-234
McDonald AD (1979) Inception of the cupule of Quercus macrocarpa and Fagus grandifolia. Can J Bot 57, 1777-1782

McNeilly T, Antonovics J (1968) Evolution in closely adjacent plant populations. IV. Barriers to gene flow. Heredity 23, 205-218

Mellanby K (1967) The effects of some mammals and birds on regeneration of oak. $J$ Appl Ecol 5, 359-366

Merkle SA, Feret PP, Croxdale JG, Sharik TL (1980) Development of floral primordia in white oak. For Sci 26, 238-250

Miayaki M, Kikuzawa K (1988) Dispersal of Quercus mongolica acorns in a broadleaved deciduous forest. 2. Scatterhoarding by mice. For Ecol Manage 25, 9-16

Millar Cl, Riggs LA, Delany DL (1993) Genetic variability and systematics of coast live oak (Quercus agrifolia), valley oak ( $Q$ lobata) and blue oak ( $Q$ douglasii). Syst Bot (in press)

Mogensen HL (1975) Ovule abortion in Quercus (Fagaceae). Am J Bot 62, 160-165

Muller $\mathrm{CH}$ (1951) Significance of vegetative reproduction in Quercus. Madroño 11, 129-137

Müller-Starck G, Ziehe M (1991) Genetic variation in populations of Fagus sylvatica $\mathrm{L}$, Quercus robur $\mathrm{L}$ and Quercus petrae Liebl in Germany. In: Genetic Variation in European Populations of Forest Trees (Müller-Starck G Ziehe M, eds) Sauerländer's Verlag, Frankfurt, 125-140

Neilson RP, Wullstein LH (1980) Catkin freezing and acorn production in gambel oak in Utah, 1978. Am J Bot 67, 426-428

Niklas KJ (1985) The aerodynamics of wind pollination. Bot Rev 51, 328-386

Olivieri I, Couvet D, Gouyon PH (1990) The genetics of transient populations: research at the metapopulation level. Tree 5, 207-210

Olsson U (1975) On the size and microstructure of pollen grains of Quercus robur and $Q$ petraea (Fagaceae). Bot Not 128, 256-264

Orsini P (1979) Recherches sur les rongeurs de quelques formations à chênes du midi de la France. Mém École Prat Hautes Études, Montpellier, France

Pjatniski SS (1947) On pollination in oaks and the germination of pollen on the stigmas. Dokl Akad Nauk SSSR 56, 545-547 (in Rus. sian) 
Rameau JC (1987) Contribution phytoécologique et dynamique à l'étude des écosystèmes forestiers : applications aux forêts du nordest de la France. Thesis, Univ Nancy, France

Rice WR (1984) Disruptive selection on habitat preference and the evolution of reproductive isolation: a simulation study. Evolution 38, 1251-1260

Rushton BS (1976) Pollen grain size in Quercus robur $\mathrm{L}$ and Quercus petraea (Matt) Liebl. Watsonia 11, 137-140

Rushton BS (1977) Artificial hybridization between Quercus robur $L$ and Quercus petraea (Matt) Liebl. Watsonia 11, 229-236

Salisbury EJ (1942) The Reproductive Capacity of Plants: Studies in Quantitative Biology. G Bell and Sons, London

Scaramuzzi $F$ (1958) Osservazioni su anomalie dei fiori in Quercus coccifera L. Nuovo Giorn Bot ltal 45, 380-388

Scarlett TL, Smith KG (1991) Acorn preference of urban blue jays (Cyanocitta cristata) during fall and spring in northwestern Arkansas. Condor $93,438-442$

Schnabel A, Hamrick JL (1990) Comparative analysis of population genetic structure in Quercus macrocarpa and $Q$ gambelii (Fagaceae). Syst Bot 15, 240-251

Schwarzmann JF (1991) Genetic structure and mating system of northern red oak (Quercus rubra L) in Pennsylvania. For Sci 37, 13761389

Sharp WM (1958) Evaluating mast yields in the oaks. Pa Agric Exp Stn Bull 635, 22 pp

Sharp WM, Chisman HH (1961) Flowering and fruiting in the white oaks. I. Staminate flowering through pollen dispersal. Ecology 42, 365-372

Sharp WM, Sprague VG (1967) Flowering and fruiting in the white oaks. Pistillate flowering, acorn development, weather, and yields. Ecology 48, 243-251

Shaw MW (1974) The reproductive characteristics of oak. In: The British Oak (Morris MG, Perring FN, eds) EW Classey LTD, London, 162-181

Skellam JG (1951) Random dispersal in theoretical populations. Biometrica 38, 196-218

Slatkin M (1978) Spatial patterns in the distribution of polygenic characters. $J$ Theor Biol 70 , 213-228
Slatkin M (1987) Gene flow and the geographic structure of natural populations. Science 236 , 787-792

Smith CC, Hamrick JL, Kramer CL (1990) The advantage of mast years for wind pollination. Am Nat 136, 154-166

Smith KG (1986a) Winter population dynamics of blue jays, red-headed woodpeckers, and northern mockingbirds in the Ozarks. Am Midl Nat 115, 52-62

Smith KG (1986b) Winter population dynamics of three species of mast-eating birds in the eastern United States. Wilson Bull 98, 407-418

Smith KG, Scarlett $T$ (1987) Mast production and winter populations of red-headed woodpeckers and blue jays. $J$ Wild Manage 51, 459-467

Solomon AM (1983a) Pollen morphology and plant taxonomy of white oaks in eastern North America. Am J Bot 70, 481-494

Solomon AM (1983b) Pollen morphology and plant taxonomy of red oaks in eastern North America. Am J Bot 70, 495-507

Sork VL (1984) Examination of seed dispersal and survival in red oak, Quercus rubra, using metal-tagged acorns. Ecology 65, 1020-1022

Sork VL, Huang S, Wiener E (1993) Macrogeographic and fine-scale in a North American oak species, Quercus rubra L. Ann Sci For (suppl 1), 261s-270s

Stairs GR (1964) Microsporogenesis and embryogenesis in Quercus. Bot Gaz 125, 115121

Stapanian MA, Smith CC (1978) A model for scatterhoarding: coevolution of fox squirrel and black walnuts. Ecology 59, 884-896

Stebbins GL Jr (1950) Variation and Evolution in Plants. Columbia Univ Press, New York

Stephenson AG (1981) Flower and fruit abortion: proximate causes and ultimate functions. Annu Rev Ecol Syst 12, 253-279

Sutherland S (1986) Patterns of fruit-set: what controls fruit-flower ratios in plants? Evolution $40,117-128$

Tauber H (1977) Investigations of aerial pollen transportation in forested area. Dan Bot Ark 32, 1-121

Thiébaut B, Cuguen J, Comps B, Merzeau D (1990) Genetic differentiation in beech ( $\mathrm{Fa}$ gus sylvatica $L$ ) during the periods of inva- 
sion and regeneration. In: Biological Invasions in Europe and the Mediterranean Ba$\sin$ (Di Castri F, Hansen AJ, Debussche M, eds) Kluwer Acad Publ, Dordrecht, 379-390

Tucker JM (1972) Hermaphroditic flowers in Californian oaks. Madroño 21, 482-486

Tucker JM, Neilson RP, Wullstein H (1980) Hermaphroditic flowering in gambel oak. $A m \mathrm{~J}$ Bot 67, 1265-1267

Tucovic A, Jovanovic M (1970) Some characteristics of meiosis in common oak (Quercus robur L). In: Sexual Reproduction of Forest Trees (Valtion P, ed) IUFRO, Varparanta, Finland, 41-42

Van Dersal WR (1940) Utilizations of oaks by birds and mammals. $J$ Wild Manage 4, 404428

Van Valen L (1976) Ecological species, multispecies, and oaks. Taxon 25, 233-239

Vasquez FM, Esparrago F, Lopez Marquez JA, Jaraquemada F (1990) Flowering of Quercus rotundifolia Lam. In: International Workshop, Quercus ilex L Ecosystems: Function, Dynamics and Management. Montpellier-Barcelona, September 17-21, 1990. CEPE/CNRS, p 84

Vincent JP (1977) Interaction entre les micromammifères et la production de semences forestières. Ann Sci For 34, 77-87

Vogt AR (1969) Reproduction of the oak. Ohio Rep 54, 19-21

Vuillemin J (1978) La régénération des chênes méditerranéens : Quercus ilex et Quercus pubescens. Thesis, Univ Marseille, France

Webb DA (1966) Dispersal and establishment: what do we really know? In: Reproductive Biology and Taxonomy of Vascular Plants. Bot Soc Br sles Conf Rep No 9, 93-102

Webb SL (1986) Potential role of passenger pigeons and other vertebrates in the rapid holocene migrations of nut trees. $Q$ Res 26 , 367-375
Whittemore AT, Schaal BA (1991) Interspecific gene flow in oaks. Proc Natl Acad Sci USA $88,2540-2544$

Wigston DL (1975) The distribution of Quercus robur L, $Q$ petraea (Matt) Liebl and their hybrids in south-western England. 1. The assessment of the taxonomic status of populations from leaf characters. Watsonia 10, 345369

Williamson MJ (1966) Premature abscissions and white oak acorn crops. For Sci 12, 19-21

Wolgast LJ (1978a) Effects of site quality and genetics on bear oak mast production. $A m J$ Bot $65,487-489$

Wolgast LJ (1978b) A study of variability in the production of immature acorns in bear oak. Bull N J Acad Sci 23, 21-25

Wolgast LJ, Stout BB (1977a) The effects of relative humidity at the time of flowering on fruit set in bear oak (Quercus ilicifolia). Am J Bot $64,159-160$

Wolgast LJ, Stout BB (1977b) Effects of age, stand density, and fertilizer application on bear oak reproduction. $J$ Wild Manage 41, 685-691

Wolgast LJ, Zeide B (1983) Reproduction of trees in a variable environment. Bot Gaz 144, 260-262

Wood OM (1938) Seedling reproduction of oak in southern New Jersey. Ecology 19, 276293

Wright S (1951) The genetical structure of populations. Ann Eugen 15, 323-354

Yacine A, Lumaret R (1988) Distribution spatiale des génotypes dans une population de chêne vert (Quercus ilex $\mathrm{L}$ ), flux génique et régime de reproduction. Genet Sel Evol 20, 181-198

Yacine A, Lumaret $R$ (1989) Genetic diversity in Holm-Oak (Quercus ilex $L$ ) insight from several enzyme markers. Silvae Genet 38, 3-4 